\title{
On the Formation of Environmental Normative Criteria: Bioethics as a Dead End
}

\author{
0 tworzeniu normatywnych kryteriów środowiskowych: bioetyka jako ślepy zaułek
}

\author{
Eva Smolková \\ Institute of Philosophy, Slovak Academy of Sciences, Slovakia \\ ORCID https://orcid.org/0000-0003-1450-8692•smolkovaeva@gmail.com \\ Received: 07 July, 2021; Revised: 06 Aug, 2021; Accepted: 10 Aug, 2021
}

\begin{abstract}
The need to reflect upon the environment and the creation of a concept of environmental philosophy resonated in the philosophical thinking of the 1980 s and 1990s. It seems that the advent of national and international institutions, which were "given" the responsibility for environmental issues, the importance of creating environmental principles, and pursuing environmental goals, has seemingly dwindled. The relationship with the environment has turned into the relationship of a citizen to his or her country, and with the principles and standards taking the form of legal regulations, the issue quickly became a matter of abiding by the law. Whilst discussion on how the normative criteria are set continued, its focus shifted to the questions of how and why they should be gradually made stricter, factoring in the economic interests of enterprises, and the time needed for setting up the processes, and developing new technologies. Environmental philosophy gradually integrated into bioethics in a broader context. This paper discusses the question of whether the integration of the environmental philosophy of bioethics helped to better promote the idea of environmental responsibility and environmental ethics, or otherwise. The study aims to initiate a discussion on whether this was a step in the right direction, and to assess how effective it was in relation to the pursuit and formation of environmental criteria.
\end{abstract}

Keywords: environmental philosophy, bioethics, human rights, anthropocentrism, the principle of responsibility

Streszczenie: Potrzeba refleksji nad środowiskiem i stworzenie koncepcji filozofii środowiskowej odbiła się echem w myśleniu filozoficznym lat 80. i 90. XX wieku. Wraz z pojawieniem się instytucji krajowych i międzynarodowych, które "obarczono" odpowiedzialnością za kwestie środowiskowe, znaczenie tworzenia zasad ochrony środowiska i dążenia do celów środowiskowych pozornie zmalało. Relacja ze środowiskiem przekształciła się w relację obywatela do swojego państwa, a wraz z zasadami i normami w postaci regulacji prawnych kwestia ta stała się kwestią przestrzegania prawa. W toku dyskusji nad ustalaniem kryteriów normatywnych skupiono się na pytaniach, jak i dlaczego należy je stopniowo zaostrzać, uwzględniając interes ekonomiczny przedsiębiorstw oraz czas potrzebny na uruchomienie procesów i opracowanie nowych technologii. Filozofia środowiskowa stopniowo integrowała się z bioetyką w szerszym kontekście. W artykule odniesiono się do pytania: czy integracja środowiskowej filozofii i bioetyki pomogła w lepszym promowaniu idei odpowiedzialności środowiskowej i etyki środowiskowej, czy też nie. Opracowanie to ma na celu zainicjowanie dyskusji na temat tego, czy był to krok w dobrym kierunku oraz ocenę jego skuteczności w realizacji i kształtowaniu kryteriów środowiskowych.

Słowa kluczowe: filozofia środowiskowa, bioetyka, prawa człowieka, antropocentryzm, zasada odpowiedzialności 
"After twenty years of writing and thinking, there seems to be no guidance on how to live with Gaia; we only know the consequences of our past attempts."

James Lovelock

\section{Introduction}

The philosophical reflection upon environmental issues, is often labelled as an ecological problem or crisis, primarily revolving around the gradual degradation of the environment, destruction of biotopes, and the worsening quality of the environment on Earth. As we have become acquainted with the functioning of ecosystems and gained a better grasp of the planetary mechanisms, ecosystems, and prerequisites of life's permanence on the planet, ${ }^{1}$ the issues studied by environmental philosophy and ethics have been changing hand in hand with that.

The issue itself, now concerns virtually all disciplines of science, including the technical ones. Researchers in various areas are paying special attention to the human impact on individual environmental factors, and the changes that are attributed to the activity of human civilisation. They also study human impact on the environment and the factors that influence the quality of the environment, biodiversity, and other key factors of life on the planet. The conditions of life and survival have traditionally been a philosophical issue with clear ontological significance. The need to accept the intrinsic values of nature, which are independent of the entity that evaluates them, was the basis for the principles of environmental philosophy and ethics.

\section{A note on the rise of environmental thinking}

Everything related to environmental changes and the human impact on environmental

1 In the early days of environmental thinking, philosophers expressed the need to keep living conditions unchanged. However, in recent decades, it has become apparent that changes that have taken place so far are irreversible, and thus, the conditions of life on the planet are changing as well. factors, is seen as a relatively young issue, having been studied by analysts of various scientific disciplines, including philosophers, since the 1970s. Based on long-term observations of the impact of human interference with the environment, various 2 oth-century authors identified the key reasons for the changes, and sought ways of influencing or fundamentally changing the processes that started them, and are still present in various cultures. Whilst scholars started to gather knowledge and information on the risk factors of ecosystems and planetary mechanisms, there was an influx of new views on why the situation occurred in the first place. They were trying to identify the reasons behind human civilisation seeing the natural environment as a thing, an irrelevant factor, or even a source of income, and an instrument of achieving prosperity. Furthermore, they sought to answer the question of how modern civilisation should view the environment, and what are the necessary changes that need to take place, if individual and social attitudes in various cultures on Earth are to finally change.

We need to realise that until the 1950s, any reflection of the environment was basically unnecessary. ${ }^{2}$ The environment was taken for granted as an insignificant factor - irrelevant even - with no impact on the social situation and, at most, a marginal influence on people's lives. There were discussions on why humans, who are determined by their social environment, see the natural one only from a utilitarian perspective, namely, in terms of benefit that it can bring to people. The natural environment was perceived as having its significance, but this was seen, primarily, in economic terms. After natural resources were exhausted, it was possible to "move" to another place and start again, with the extraction process showing no regard for the possibility of their exhaustion. Study of the reasons why the environment

2 This is not without exceptions, though, as by the end of the 19th century, the city council in London banned solid fuel heating at a certain point, due to air pollution in the city. 
had not been a factor significant for survival, as well as why it was not necessary to consider it a major influence on human living conditions, became a central topic in philosophy. Though the identification of the causes is important, most authors focused, primarily, on the need to react to the change. This required a transformation in the conditions of people's actions, which would only be possible if new ethical principles were introduced, and a basis for a new kind of moral standards was formed (Jonas 1984; Skolimowski 1981; Sessions 1995; Taylor et al. 2011; Medows et al. 1972, etc.). We, thus, saw a need for new principles that would allow for a systemic change, seen by some as a paradigmatic one, in terms of our relationship to the environment. It is one thing to speak of new moral, normative, and legal criteria that would account for long-term environmental conditions of life; it is a different thing to see those accepted by society and various cultures. Moreover, it is a long-term process that takes years or even decades, and neither the methodologies, nor the tools for its promotion, exist; they first need to be created and implemented.

The current state has been attributed to various causes; however, anthropocentrism is most frequently cited as the cause, by authors coming from diverse theoretical backgrounds. Anthropocentrism is, thereby seen as the "culprit" in how man, and human civilisation in general, relates to the environment; it is seen as the reason behind the "distancing" from nature, and nature becoming regarded as a "useful" thing, an estranged tool of human interest, to such an extent, that natural attributes, along with plant and animal species have been categorised, according to the spheres of human interest, and the extent, to which, society can benefit from them. This was an analysis of the loss of the value of nature. Now, if we state that anthropocentrism was labelled as the "culprit", we can only reflect upon the group of theoreticians, who have agreed with this notion. However, the spectrum of the opinions has been incredibly diverse, ranging from those who defend anthropocentrism to proponents of biocentrism. Nevertheless, the consequences of relating to the environment were so obvious, that scholars started to look for alternative models and tools, to change our approach. They pondered if it was possible to alter the anthropocentric attitude, and if it was possible at all to form a concept of biocentric principles. We saw the appearance of both holistic and pantheistic concepts (Lovelock 2000; Sessions 1995), with some articulating the necessity to rehabilitate utilitarianism, should environmental factors such as biodiversity be included in the prerequisites of survival, and thought was given to the question: which newly created principles would allow for such a thing to happen? As an attractive notion of a harmonious relationship between society and nature, biocentrism has been an enticing idea. However, it has only been seen as a vision of the future, similar to the concept of nature's sanctity, that considers the ecological and the spiritual to be the same thing and calls for respect to life and everything that exists. The idea that the sanctity of nature would be the basis for the notion of being responsible for the world and society (Skolimowski 1981), has not gained ground, neither in church nor society.

Utilitarianism, the ability to view the world exclusively through the prism of human benefit, was deemed to be problematic. Therefore, some thinkers rejected it, and tried to work with the strengthening of personal responsibility, which ideologically, was based on deontological ethics, and appealed to individual responsibility. Limits on the use of natural resources, in particular, fossil resources, and ways of reversing certain processes, including pollution, were considered. Most of the solutions proposed were partial and addressed specific problems in specific countries. A breakthrough occurred at the time of the publication of the Growth Limits from the Rome Club workshop in 1972. For the first time, environmental issues were presented as a global 
problem. It became clear that environmental problems transcended the boundaries of any scientific discipline or national boundaries. The term "ecological crisis" was introduced, and the concept of sustainability came into consideration.

At that time, humanity had minimal experience with tackling environmental issues, and the solutions were solely partial. In order to understand factors with major impact on environmental sustainability and biodiversity, as well as to permanently mitigate, stop, or even reverse ${ }^{3}$ devastating activities, numerous scientific analyses were necessary. It was assumed that afterwards, strategies valid for the whole of humanity would be established. ${ }^{4}$ The first global summit was held in Rio de Janeiro in 1992. It was more than obvious, that in order to solve the global issue, it was necessary to grasp the problem itself, comprehensively and systematically, across entire sciences and all cultures. What proved to be necessary in the coming years, was the need to involve, not only scientists, but also politicians, in dealing with environmental issues, because it was necessary, to name the issues, as well as find and implement concrete steps, to restore and protect the environment. Political instruments have always been the responsibility of specific governments. Therefore, the international community looked for a way to obtain the consent of local governments, to documents that were created under the auspices of the United Nations as multicultural (2015 Paris Climate Agreement ${ }^{5}$ ), and through

3 The concept of zero growth was based on the limitation of all economic activities that affect the environment.

4 Regardless of the extent to which individual countries participated in the past. The processes were supposed to be set up for the future.

5 The Paris Agreement is an agreement under the UN Framework Convention on Climate Change, to limit greenhouse gas emissions beyond 2020, and to follow up on the Kyoto Protocol. The Agreement was negotiated during the Paris Climate Conference in 2015, and approved by all 195 parties. It was adopted on the 12 December, 2015, and signed on the 22 April, 2016, on Earth Day, by which, the individual states would agree with specific solutions to individual issues. It turned out that the ideas of how to enforce specific solutions differ from one country to another, whilst the commitment of one politician, does not have to be the commitment of his successor in office. ${ }^{6}$ The pressure from the public and NGOs was so great, given the urgency and grave nature of the subject, that we saw the advent of political entities, that would promote the concept of sustainable development. ${ }^{7}$ At the same time, these ideas were also adopted by standard political entities, considering it an opportunity to gain more ground in their political struggles. The situation gave rise to the ideas of environmental responsibility. This, in turn, helped derive subsequent political objectives, and finding a solution to environmental problems became a priority, in accordance with the preferences of the parties' voters. Given the existing political polarisation - the left and the right - this proved to be tricky. No other political orientation appeared, and ultimately, most political entities that preferred environmental goals in their programmes, were gradually integrated amongst left-wing parties. This happened despite the fact that the parties labelled themselves as the "greens" to indicate their focus. This was supposed to simplify their identification and draw attention to the prominent position of environmental policies. However, as the parties had to tackle standard socio-political and economic issues, the distinctiveness of these political subjects amongst standard ones, gradually faded away. ${ }^{8}$

177 member states of the UN Framework Convention on Climate Change (UN 2015).

6 US President B. Obama signed the Paris Climate Agreement, but his successor D. Trump withdrew his consent to the obligations arising from it for the US.

7 The term "sustainable development" was used until the beginning of the 21st century and is now replaced by the term "sustainability", which is used in the same context as the previous term.

8 The pursuit of environmental goals has pro- 
While the process of identifying the reasons behind the almost exclusively utilitarian approach of people towards nature and the environment continued, this did not bring answers to the question of how the relationship to the environment could be changed, and what tools used to tackle environmental issues. When we realise that environmental issues are defined as the issue of gradual degradation of the environment, destruction of living conditions on the planet, and the issue of worsening conditions and quality of the environment on Earth, both for humans (human existence), and for other forms of life on Earth (non-human existence), we can conclude that this is, primarily, an ontological problem. The deontologisation of nature has resulted in the prioritisation of social interest, i.e., the pursuit of anthropocentric principles, which are a part of basic bioethical principles.

It has proven to be very complicated, almost impossible even, to design strategies in a way that would prevent the escalation of problems, and to set up a system to solve them efficiently, which would reflect in the global improvement of environmental quality. It should be noted that to this day, this is still the case (Singer 1995). There is a lack of comprehensive and global solutions, and the methods for changing societal attitudes, particularly market characteristics, which are actually the only ones accepted globally, have proved to be extremely complex. Although strategies were designed ${ }^{9}$ with sustainable development at their core, ${ }^{10}$ this did not prioritise environmental goals

ved to be extremely costly, with right-wing thinkers stating: "We need to make money to pay for the environmental goals!" This led to a gradual reduction of "green projects" among left-wing parties.

9 One of them is the EU's strategy for gradually reducing emissions of $\mathrm{CO}_{2}$, but it only affects countries that are in the EU.

10 At present, the word development is omitted, as its practical form and development methodologies have not been defined by anyone, and are, therefore, incomprehensible. over the economic ones in practice. This signalled a shift in opinions on the environment, and a gradually increased awareness of the existential dimension of the natural environment. As a result, this gave an impetus to draft normative criteria of our relationship with the environment on a legal level. The process of conceiving third-generation human rights had begun.

\section{Integrating environmental issues into bioethics}

As we have already mentioned, the ideas of environmental responsibility resonated in almost all cultures at the turn of the millennium. Many thinkers who tried to grasp the issue, comprehensively, encountered the need to account for four basic factors (Pellegrino 1998) - scientific progress, moral pluralism, democratisation, and the state (functioning) of the economy. All these issues have become the subject of a "new" ethical discipline - bioethics. Bioethics, ${ }^{11}$ as a term that consists of ethics - the science of morality - and the Latin word bios, meaning life, has become an "overarching" ethical discipline that emerged when the possibilities offered by modern biotechnology opened up. Bioethics was intended to, and was able to, cover a number of different schools of thought, which included, not only the possibilities of influencing what is called the natural order of things, but also issues related to one's own nature. The majority of bioethical problems had a global character from the outset, so it was assumed that global solutions would also be offered. Despite having the word ethics in its name, bioethics is also an axiological discipline that deals with sets of values, which are crucial for solving environmental problems at the level of states, business entities, and individuals. The creation and functioning of traditional and non-traditional values in connection with the emergence of new value

11 Bioethics has been forming in the US since the 1960 s, but it only began to gain ground in the latter half of the 1990s, and at the turn of the millennium. 
expectations, seemed essential for bioethics, as without them, it is impossible to examine existing and newly forming values, from a different point of view, in relation to life in human and environmental characteristics.

Bioethics has been used as a term, to describe both traditional and non-traditional ways of thinking. Since the emergence of bioethics was stimulated by the four factors mentioned above, i.e., scientific progress, moral pluralism, democratisation and the functioning of the economy, development prospects are, thus, bound to all these factors, and cannot be perceived independently of each other. Accordingly, bioethics should tackle moral problems in all four areas, as it has actually sought to do in the last 20 years. Bioethics departments were established all over the world, mostly under the auspices of UNESCO. This created a space for a comprehensive examination of the problems of humanity and grasping their moral contexts and relationships. Bioethics stemmed from traditional ethics, in connection with the emergence of new problems of ethical decision-making that resulted from the situation of a person living in the contemporary world. At the time of its creation, it primarily dealt with the creation of values and value orientations, in areas such as women's rights, animal rights, human rights, the right to health care, or the aforementioned right to a healthy environment. It responded to the emergence and functioning of biotechnology - cloning, organ replacement, programming or chipping people, possible genetic modifications etc. Yes, bioethics did respond, and very flexibly for that matter, to all the emerging problems, even if it cannot be said that it would offer global solutions. Those still remained partial. The search for the common ground between the religious and civic areas has failed. The effort to create a more flexible and dynamic moral system, and to create global bioethical principles has not yet been very successful.

In recent decades, bioethics has been intensively involved in the development of moral criteria, other than those that are directly related to the environment. Paradoxically, it was also bioethics that brought humankind's "faith" in its "omnipotence", the possibility of "restoring" habitats or ecosystems to their original state, and affecting the natural order of things, even more intensively, by using modern biotechnology and genetic engineering. Those were seen as allowing us to continuously cross the line between the possible and the real, and thus, to plan to reverse the processes that are still considered irreversible.

Bioethics, undoubtedly, has its place among modern scientific disciplines. However, if we consider whether the integration of environmental philosophy into the bioethics system was the right step to shift its focus to changing attitudes towards the environment, and promote the principle of responsibility, by extending societal and individual moral obligations (Jonas 1984, 178), the answer is not quite straightforward. Although the merging of environmental ideas with other areas of bioethics has contributed to a more intensive and systematic examination of the environment, from a scientific point of view, it has not contributed to changes in moral attitudes and opinions. It can even be said that environmental philosophy has ceased to be a key issue in bioethics and has become merely partial. Philosophical attitudes have been taken into account, but moral pluralism in relation to the environment seems to indicate not only several possible approaches, but also a multitude of solutions. The problems have been dispersed in the bioethics system because it is not easy and, we dare say, practically possible, to grasp them comprehensively across the four mentioned areas.

It is still not possible to speak of bioethics as a definitely global discipline. Intuitively, we know that it should be such, but we still do not have an answer to the question of which ideas and principles it should be based on, and subsequently implemented. Efforts in this direction - both religious and civic - have shown that global implementation is not acceptable to a large part 
of the planet's population. Is it then possible to speak of bioethics as a global scientific discipline?

Bioethics, unlike most scientific disciplines, has a number of diverse opinion streams with different attitudes and preferences that stem from the diversity of cultural environments. The need for global bioethics, as we have already indicated, is logical, because a global problem requires global solutions, but bioethics has provided them only to a very small extent. Therefore, if we are to conclude this reflection, then the integration of environmental philosophy into the bioethics system has been clouded by being already merged with other bioethical problems. Environmental issues, as well as discussions on the ontological dimension of the environment, have ceased to be the focus of attention, as if they had returned to their "defined space". It is difficult to see this step as beneficial in terms of environmental philosophy, but it is, of course, up to the reader to evaluate it.

\section{The right to a favourable environment as a human right}

Over the past decades, in parallel with the development of bioethics, the need to develop normative criteria that would integrate environmental protection into the legal system for the sake of society, arose. In the European context, this resulted in the articulation of the right to environmental protection, ${ }^{12}$ created as an obligation for member states of the European Union to create such legislative standards that would ensure ecological safety for present and future generations. ${ }^{13}$ These are mostly

12 Articles 44 and 45 of the Constitution of the Slovak Republic.

13 Article 74 of the Constitution of the Republic of Poland contains the following four points 1. Public authorities implement a policy ensuring ecological safety for present and future generations. 2 . The protection of the environment is the responsibility of the public authorities. 3. Everyone has the right to information about the state and protection of the environment. 4. Public authorities standards that have become part of the key documents of the state, for instance, they are part of constitutional rights. All such legislation concerns citizens of a particular country. However, not all states recognise the need for "protection" of the environment and have it in their legal systems. ${ }^{14}$

When we think about why legal standards of environmental "protection" have been established, we have to admit that it is a rational effort to regulate the impact of social, and especially economic, activities on the natural environment. The normative criteria, in relation to society and the environment, set limits that become legal standards. The aim is to ensure that environmental criteria are in place to guarantee the right to a favourable environment for citizens of the state. Such a right is specified as the lowest possible degree of pollution or damage to the environment, in order to ensure the protection of the health of citizens of the state. This is, more precisely, to prevent the health consequences that greater pollution of the environment, than the limit stipulated by law, could cause. The question is whether it is possible to establish such a public policy that would be guaranteed by the state, and allow it to protect the environment from people, i.e., the citizens of the state? The only viable way forward has proved to be, in the context of existing rights, to create the right to a healthy environment, and to integrate it into the system of human rights. Although the paradox of this step is evident, because it made society, or, more precisely, the state, the guarantor of environmental quality, taking a different step was not possible within the legal system. In the context of the issue, we still need to say that talking about national borders as the boundaries of nature protection is fundamentally nonsensical, but since

support action by citizens to protect and improve the environment.

14 The guarantor is the state, which usually establishes a separate ministry for this purpose an administrative and executive body dealing with environmental issues. 
the entire system of human rights is based on a state guarantee, the term "environment" in the state, however problematic, describes the need to ensure that appropriate living conditions of every citizen of the state, including those related to the environment, are maintained.

The right to a favourable environment is seen as a collective right, often referred to as the third generation of human rights, or the so-called "third-wave" human rights. ${ }^{15}$ Unlike the previous ones, it has formed differently, often without negative experience, or more precisely, to avoid negative experience. ${ }^{16}$ The right to a healthy environment is introduced into national laws when the states accept such an obligation. The state is the guarantor of these rights, but a need for an international context, i.e., the need to ensure the same (or at least similar) implementation in different states, is becoming increasingly evident. The vision of "global citizenship" is most relevant to these types of rights, and it is desirable to prefer this idea, because ethical particularism leads to the prioritisation of one's own citizens and their interests, precisely in the field of distribution of natural resources (Sedová 2008), and it turns out that "if it means a worsening of the living standards in rich countries, it can be rejected, with the argument that obligations towards fellow citizens are more important than those towards foreigners" (Palovičová 2014, 58).

Effective protection of the environment presupposes effective state power. States have assumed the role of guarantor and must comply with their contractual obligations. However, the contractual relationship does not exist between nature and society, so only persons, enterprises, municipalities, or cities that have been proven to be medically or economically damaged by specific

15 These consist of the right to development, peace, a clean (healthy) environment, or the right to a guaranteed income.

16 The idea that there is no negative experience of environmental devastation is rather an illusion in times of climate change. actions of an entity, causing the worsening of environmental quality, may demand fulfilment of the relevant obligations. It is probably obvious that this seems to be quite a riddle. Nevertheless, it should be noted that with regard to criminal law, we are talking about environmental crime and crimes against the environment. However, a state, which does not respect the right to a favourable environment, is unaffected when the other contractual party reacts by failure to comply with its human rights obligations towards the environment. Therefore, this human right can only be regarded as an objective regulation that does not oblige the state to actually implement it (Pollmann and Lohmann 2017, 148). The right confers a certain entitlement of the holder and obliges the subjects of the right to behave in a certain way. Having a right means that someone, in our case the state, has a certain obligation and citizens can claim for it to be fulfilled. The citizen even has a duty to protect and look after the environment, ${ }^{17}$ and "must not endanger or harm the environment and natural resources, above and beyond the limits set by law" ${ }^{18}$ The formulation "above and beyond the limits set by law" predicts the fact that only the legal norm may not be overstepped, and not the moral one, which indicates the responsible behaviour of the individual on the basis of moral principles and standards.

Let us note that ensuring universal care and creating the conditions for citizens to enjoy the right to a favourable environment does not have strictly prescribed rules. This means that a norm is created, but the principle or a particular way of enforcing the law is often absent. The claimability or enforceability of this right, thus, often depends on the "image of a person", more precisely on what the citizen of the state has

17 Section 6 of the Constitution of the Slovak Republic, Articles 44 and 45. Environmental protection is associated with the protection of cultural heritage in the Slovak Constitution.

18 Section 6 of the Constitution of the Slovak Republic, Articles 44 and 45. 
the right to do, and on whether resources are allocated for the implementation of this right. ${ }^{19}$ Therefore, individual models also vary in the countries of the European Union, and the implementation of the same law takes different forms in different countries. The current form of the right to a healthy environment, but also the protection of nature in the state, depends not only on legislation, but also on the culture and moral principles applicable in society. What is more, this also depends on democratisation processes and the economic interests of countries, because in the process of enforcing the rights to the protection of nature, the transformation of abstract means into capabilities ${ }^{20}$ is duly problematic, and the effort to ensure a good, or full life, for its citizens, is currently, fully within the competence of the state.

\section{Conclusion}

As part of the introduction to the issue, we have provided the reader with a brief history of environmental thinking. We did so to show whether and how basic philosophical approaches to the environment had formed, and what principles of establishing a relationship with the issue were created. We stated that the causes were intensively sought and indicated solutions that were proposed. We have demonstrated that anthropocentrism was named as the approach that most significantly influenced the relationship of humans and society to nature and the environment, and we have pointed out that this is still a valid thesis, which no one has refuted. In the aforementioned period, environmental philosophy was at the centre of philosophical thinking, environmental ideas resonated with moral and social philosophy and, of course, with many other scientific disciplines. The effort to create global approaches to the environment resulted in

19 Resources must also be set aside for old environmental burdens.

20 Non-governmental organisations whose mission is to protect nature also play an important role in this process. the integration of environmental issues into the bioethics system, where, however, environmental philosophy merged with other areas of focus. While attempting to create a more comprehensive system, addressing all foci of bioethics was logical and justifiable, and it resulted in what could only be described as a dampening of the dynamics of environmental approaches, not to mention the fact that attention shifted to other topics. Therefore, the integration of environmental philosophy into the bioethics system from the perspective of promoting the idea of environmental responsibility and environmental ethics, is a step that can be assessed as questionable. The arguments in this respect are either completely absent, or simply, not put forward by anyone.

What could then be the basis of any conclusions? Most importantly, not only did the anthropocentric approach fail to change, but that approach towards the environment and nature as a whole, has become even stronger. It has taken on a different form, but the determinative nature of social priorities is evident in the contemporary world. Man still considers himself primarily a social being, but modern anthropocentrism recognises his biological needs and limits. It merely states that everyone needs an adequate natural environment, in order to lead a full life. The guarantor of the quality of the environment was the state, which responded not only to the lack of legal, but also moral criteria of relating to the environment in a culture. Therefore, standards such as the legal normative criteria that set certain environmental limits have been incorporated into the legal system. However, the problem has been the time needed to set up the processes and social changes, which are necessary for both individuals and society as a whole, to start behaving responsibly and to cease to prefer exclusively economic interests. The right of citizens of particular states to a favourable environment as a human right, was a concept that was feasible and possible to execute in a relatively short period of time. Assessing the level 
of environmental pollution exclusively, in relation to human beings, is a purely anthropocentric approach, so it can be said that it has not only gained a key role, but also strengthened its position. The strategy of relating to the environment was launched at the level of practical policies of national states and international groups. This automatically implies that the norms are set by politicians, whose performance is assessed by indicators of economic growth, and the well-being of citizens during their rule. Stricter environmental criteria can, therefore, only be enshrined within the framework of environmental legislation. If standards that guarantee the protection of the environment have been incorporated into the legal systems, and legal limits have been created to affect the behaviour of individuals, including enterprises, then it seems that nothing more is to be done. That would be true, if it were not for the reality of the climate crisis, the extinction of species, and other problems that indicate changes in planetary mechanisms, despite the existence of legal norms created within the third wave of human rights.

Environmental philosophy is, nowadays, primarily a social philosophy that solves politological problems. It responds to the fact that the enforceability of the right to a healthy environment is similar to that of other collective rights - very low, or even questionable - because most of the time, it is a declaratory right. There is no accountability of society. Accountability always applies to a specific entity, and if it pertains to criminal accountability, it is only possible to grasp it in the case of acts that have proven to be harmful to the environment. Without a specific way of enforcing the right to a healthy environment (Palovičová 2017, $68)$, this is only a thesis which the state claims to respect. We can thus conclude that the effort to ensure ecological safety, within the boundaries defined by legal instruments, was a rational step, in relation to the stability of ecosystems and nature as a whole.

Funding: This research was funded by the VEGA project
2/0049: On the Idea of Human Rights: A Philosophical Perspective - Concepts, Issues and Contradictions. Project duration 2020-2023.

Institutional Review Board Statement: Not applicable.

Conflicts of Interest: The founding sponsors had no role in the design of the study; in the writing of the manuscript, and in the decision to publish the results.

\section{References}

Constitution of the Republic of Poland. Accessed July 03, 2021. https://www.sejm.gov.pl/prawo/konst/ angielski/kon1.htm.

Constitution of the Slovak Republic. Accessed July 03, 2021. https://archiv.vlada.gov.sk/old.uv/data/ files/6486.pdf

Jonas, Hans. 1984. Das Prinzip Verantwortung: Versuch einer Ethik für die technologische Zivilisation. Frankfurt am Main: Suhrkamp.

Lovelock, James. 2000. Gaia: A New Look at life on Earth. Oxford: Oxford University Press.

Meadows, Donella H., Jorgen Randers, and Dennis L. Meadows. 1972. The Limits to Growth. A Report for the Club of Rome's Project on the Predicament of Mankind. New York: University Book.

Palovičová, Zuzana. 2014. Spravodlivost’ ako problém sociálnej filozofie. [Justice as a problem of social philosophy]. Trnava: Univerzita sv. Cyrila a Metoda.

Palovičová, Zuzana. 2017. Ambivalentnost' l'udský práv a neurčitost' ich pojmu z pohl'adu filozofie. [Ambivalence of the human rights and uncertainty of their concept from the point of view of philosophy]. Bratislava: VEDA.

Pellegrino, Edmund D. 1998. "Einleitung: Die medizinische Ethik in den USA - Die Situation heute und die Aussichten für morgen." In Bioethik in den USA, edited by Hans-Martin Sass, 1-18. Heidelberg: Springer.

Pollmann, Arnd, and Georg Lohmann. 2017. Ludské práva - interdisciplinárna príručka. [Human rights - an interdisciplinary handbook]. Bratislava: Kalligram.

Sedová, Tatiana. 2008. „K pojmu ludskej prirodzenosti a kultúry a k ich funkcii v sociálnom poznaní." [On the concept of human nature and culture and their function in social knowledge]. Filozofia 63(8): 657-669. 
Sessions, George. 1995. Deep ecology for the twentyfirst century. Boston: Shambhala.

Singer, Peter. 1995. Animal Liberation. New York: Vintage Publishing.

Skolimowski, Henryk. 1981. Eco-Philosophy, Designing New Tactics for Living. Boston: Marion Boyars.
Taylor, Charles, Amy Gutmann, Anthony Appiah, Jurgen Habermas, Stephen C. Rockefeller, Michael Walzer, and Susan Wolf. 2011. Multiculturalism. Princeton: Princeton University Press.

UN. 2015. "Paris Agreement.” Accessed July 03, 2021. https://unfccc.int/sites/default/files/english_paris_ agreement.pdf. 